\title{
A Comparison of Patient Outcomes Following Prosthetic Knee Replacement Using a Variety of Knee Prosthesis: A Ten-Year Study
}

\author{
Bassel El-Osta1 ${ }^{*}$, Ali Ghoz ${ }^{2}$, Alice Dawson1, Mark Andrews² \\ ${ }^{1}$ St. George's Hospital, London, UK \\ ${ }^{2}$ Scarborough General Hospital, Scarborough, UK \\ Email: ${ }^{*}$ jahed74@hotmail.co.uk
}

Received 13 July 2014; revised 29 August 2014; accepted 11 September 2014

Copyright (C) 2014 by authors and Scientific Research Publishing Inc.

This work is licensed under the Creative Commons Attribution International License (CC BY).

http://creativecommons.org/licenses/by/4.0/

(c) () Open Access

\begin{abstract}
There are several prosthetic knee designs currently in use. There are however very few studies comparing long-term functional outcomes between patients using different models of knee prosthesis in elective knee replacement. In this study, we used the validated Oxford Knee Score (OKS) to retrospectively compare the outcomes of a total of 1635 patients who had an elective total knee replacement in a large District General Hospital, using fifteen different models of knee prosthesis, over a ten-year period. The average scores reported by all patient groups showed significant improvement by three months post-operatively (pre-operative mean score 15.8, post-operative mean score 39.4, $\mathrm{p}<\mathbf{0 . 0 5}$ ), and remained similar for all models of prosthesis used over the total ten-year period. Based on the OKS as an assessment tool, we report no significant difference in long-term functional outcomes for this group of patients following an elective knee replacement, regardless of the type of prosthesis used.
\end{abstract}

\section{Keywords}

Patients Outcome, Knee Prosthesis, Total Knee Replacement, Variable Knee Prosthesis, OKS on Prosthesis

\section{Background}

Over 70,000 knee replacements are performed in the United Kingdom each year, and this number is steadily in-

*Corresponding author.

How to cite this paper: El-Osta, B., Ghoz, A., Dawson, A. and Andrews, M. (2014) A Comparison of Patient Outcomes Following Prosthetic Knee Replacement Using a Variety of Knee Prosthesis: A Ten-Year Study. Open Journal of Orthopedics, 4, 249-256. http://dx.doi.org/10.4236/ojo.2014.49041 
creasing [1]. The commonest indication for knee replacement remains degenerative osteoarthritis of the knee, and the majority of patients undergoing this operation are over 65 years of age. The vast majority of procedures are successful and patients report significantly improved pain and function in the immediate and long-term post-operative period [2]. However, the risk of post-operative complications remains; most notably, prosthetic loosening and instability, leading to prosthesis failure and the need for revision surgery. This occurrence is estimated at less than $1 \%$ per year, with an overall rate of $5 \%-10 \%$ at 10 years [3]. Prosthesis failure is a significant problem, particularly in younger, more mobile patients and in patients who are obese [4]. To combat this, several models have been designed with the aim of optimising the bone-prosthesis interface and kinetics, to improve functionality and long-term prosthesis survival.

There are currently over 50 different models of knee prosthesis in use in the United Kingdom. This broad selection of prosthesis options, in combination with the variety in patient factors, makes the choice of an optimum prosthesis for a replacement a not insubstantial task. In reality, the choice of materials for prostheses is effectively limited by the uncompromising nature of the knee joint, which creates high stresses on the surfaces in contact with the prosthesis, especially during mobilisation. Most prostheses use a combination of a metallic femoral component and a tibial component made from ultra-high molecular weight polyethylene. There are manufacturers who are exploring ceramic femoral component design. One available model has a zirconium oxide based surface (Oxinium), and is showing promising results in patients at five-year follow-up [5]. Another example is an alumina ceramic model which in laboratory studies appears to show reduced wear between articulating surfaces [6]. However as yet neither of these models has longer-term data on patient outcomes.

There are many considerations for prosthetic design. Choices must be made between unicompartmental and total replacement, the use or absence of a cemented tibial component, the use of posterior stabilised (posterior cruciate ligament-sacrificing) versus a cruciate-retaining prosthesis, fixed versus mobile bearing prosthesis, and even gender-specific prostheses [7]. In one study, by Robertson et al. [8] the cementless total knee replacement appeared to have a 1.4 times increased risk of prosthesis failure compared with total knee replacements with cemented tibial component. Even this result however does little to make the choice of prosthesis easier, as on closer inspection the risk of failure of prosthesis was strongly linked to infrequency of use of the prosthesis in knee replacement operations and hence potential lack of familiarity of the surgeon with the prosthesis used. The difficulty of choosing any particular model of prosthesis is compounded by the lack of studies comparing long-term patient outcomes following knee replacement using a wide variety of the available prostheses.

This study uses patient scores on the OKS tool to try and address the dearth of data on post-operative functional outcome between prosthesis models. We retrospectively analysed data on long-term functional outcomes in 1635 patients who had a knee replacement, using fifteen different prosthesis models, in a large District General Hospital in Yorkshire, UK. The OKS is a 12-item questionnaire which was designed for the assessment of patient symptoms and knee function, before and after a total knee replacement [9]. It has been shown to be valid, highly internally consistent and reproducible cross-culturally [10] [11]. It also correlates closely with patients' clinical status, as well as other knee scoring systems such as the American Knee Society (AKS) and relevant parts of the Stanford Health Assessment Questionnaire (HAQ) [9]. It is designed to be completed by patients, originally with a scoring system ranging from 12 (poor) to 60 (good) (Figure 1). The original scoring system was later found to be counter-intuitive and has been modified to range from 0 (poor) to a maximum of 48 (good) [12]. We used the modified OKS in our study.

In this paper we provide a direct comparison between a large number of prosthetic designs, over an extended period of time, with the aim of obtaining information about the influence, if any, of the choice of prosthesis on long-term patient outcomes after total knee replacement.

\section{Methods}

All patients who were scheduled to undergo a total knee replacement in Scarborough General Hospital completed an OKS in a face-to-face interview with a nurse specialist. Questionnaires were filled in pre-operatively and at post-operative follow-up at 3 months, 12 months, 2 years, 5 years and 10 years. Data was obtained retrospectively on 1635 patients from April 1996 to April 2008, for procedures including primary and revision replacements. Fifteen different models of prosthesis were used. We also obtained data on patient demographic details, operation performed, the operating surgeon, patient health status and complications (if any). There were 691 male and 944 female patients. The average age was 70 with a range from 34 to 94 . No exclusions were made based on complications or patient outcomes. 


\section{PROBLEMS WITH YOUR KNEE}

\begin{tabular}{|c|c|c|c|c|c|c|c|c|c|c|c|}
\hline & \multicolumn{3}{|c|}{ During the past 4 weeks.. } & \multicolumn{3}{|c|}{$\begin{array}{l}\checkmark \text { tick one box } \\
\text { for every question }\end{array}$} & \multicolumn{2}{|c|}{ During the } & \multicolumn{3}{|c|}{$\begin{array}{l}\checkmark \text { tick one box } \\
\text { for every questior }\end{array}$} \\
\hline & \multicolumn{5}{|c|}{$\begin{array}{l}\text { During the past } 4 \text { weeks...... } \\
\text { How would you describe the pain you usually have from your knee? }\end{array}$} & \multirow[t]{2}{*}{7} & \multicolumn{5}{|c|}{$\begin{array}{l}\text { During the past } 4 \text { weeks...... } \\
\text { Could you kneel down and get up again afterwards? }\end{array}$} \\
\hline & $\begin{array}{l}\text { None } \\
\square\end{array}$ & $\begin{array}{l}\text { Very mild } \\
\square\end{array}$ & $\begin{array}{l}\text { Mild } \\
\square\end{array}$ & $\begin{array}{l}\text { Moderate } \\
\square\end{array}$ & $\begin{array}{l}\text { Severe } \\
\square\end{array}$ & & $\begin{array}{l}\text { Yes, } \\
\text { Easily } \\
\square\end{array}$ & $\begin{array}{l}\text { With little } \\
\text { difficulty } \\
\square\end{array}$ & $\begin{array}{l}\text { With moderate } \\
\text { difficulty } \\
\square\end{array}$ & $\begin{array}{l}\text { With extreme } \\
\text { difficulty } \\
\square\end{array}$ & $\begin{array}{l}\text { No, } \\
\text { Impossible } \\
\square\end{array}$ \\
\hline & \multicolumn{5}{|c|}{$\begin{array}{l}\text { During the past } 4 \text { weeks } \\
\text { Have you had any trouble with washing and drying yourself } \\
\text { (all over) because of your knee? }\end{array}$} & \multirow[t]{3}{*}{8} & \multicolumn{5}{|c|}{$\begin{array}{l}\text { During the past } 4 \text { weeks. } \\
\text { Have you been troubled by pain from your knee in bed at night? }\end{array}$} \\
\hline & \multirow{2}{*}{$\begin{array}{l}\text { No trouble } \\
\text { at all } \\
\square\end{array}$} & \multirow{2}{*}{$\begin{array}{c}\text { Very little } \\
\text { trouble } \\
\square\end{array}$} & \multirow{2}{*}{$\begin{array}{l}\text { Moderate } \\
\text { trouble } \\
\square\end{array}$} & \multirow{2}{*}{$\begin{array}{l}\text { Extreme } \\
\text { difficulty } \\
\square\end{array}$} & \multirow{2}{*}{$\begin{array}{l}\text { Impossible } \\
\text { to do } \\
\square\end{array}$} & & $\begin{array}{l}\text { No } \\
\text { nights } \\
\square\end{array}$ & $\begin{array}{l}\text { Only } 1 \text { or } 2 \\
\text { nights } \\
\square\end{array}$ & $\begin{array}{l}\text { Some } \\
\text { nights } \\
\square\end{array}$ & $\begin{array}{l}\text { Most } \\
\text { nights } \\
\square\end{array}$ & $\begin{array}{l}\text { Every } \\
\text { night } \\
\square\end{array}$ \\
\hline & & & & & & & \multirow{2}{*}{\multicolumn{5}{|c|}{$\begin{array}{l}\text { During the past } 4 \text { weeks..... } \\
\text { How much has pain from your knee interfered with your usual work } \\
\text { (including housework)? }\end{array}$}} \\
\hline & \multirow{2}{*}{\multicolumn{5}{|c|}{$\begin{array}{l}\text { During the past } 4 \text { weeks } \\
\text { Have you had any trouble getting in and out of a car or using public } \\
\text { transport because of your knee? (whichever you would tend to use) }\end{array}$}} & \multirow{7}{*}{$\begin{array}{r}9 \\
10\end{array}$} & & & & & \\
\hline & & & & & & & Not at all & A little bit & Moderately & Greatly & Totally \\
\hline & \multirow{2}{*}{$\begin{array}{l}\text { No trouble } \\
\text { at all } \\
\square\end{array}$} & \multirow{2}{*}{$\begin{array}{l}\text { Very little } \\
\text { trouble } \\
\square\end{array}$} & \multirow{2}{*}{$\begin{array}{c}\text { Moderate } \\
\text { trouble } \\
\square\end{array}$} & \multirow{2}{*}{$\begin{array}{c}\text { Extreme } \\
\text { difficulty } \\
\square\end{array}$} & \multirow{2}{*}{$\begin{array}{c}\text { Impossible } \\
\text { to do } \\
\square\end{array}$} & & 口 & 口 & 口 & 口 & $\square$ \\
\hline & & & & & & & \multirow{2}{*}{\multicolumn{5}{|c|}{$\begin{array}{l}\text { During the past } 4 \text { weeks } \\
\text { Have you felt that your knee might suddenly 'give way' or let you } \\
\text { down? }\end{array}$}} \\
\hline & \multirow{2}{*}{\multicolumn{5}{|c|}{$\begin{array}{l}\text { During the past } 4 \text { we } \\
\text { For how long he }\end{array}$}} & & & & & & \\
\hline & & & & & & & $\begin{array}{c}\text { Rarely/ } \\
\text { never }\end{array}$ & $\begin{array}{l}\text { Sometimes, or } \\
\text { just at first }\end{array}$ & $\begin{array}{l}\text { Often, not } \\
\text { just at first }\end{array}$ & $\begin{array}{l}\text { Most of } \\
\text { the time }\end{array}$ & $\begin{array}{c}\text { All of } \\
\text { the time }\end{array}$ \\
\hline & 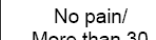 & & & & Not at all & & & & & & \\
\hline & $\begin{array}{c}\text { More than } 30 \\
\text { minutes } \\
\square\end{array}$ & $\begin{array}{l}16 \text { to } 30 \\
\text { minutes } \\
\square\end{array}$ & $\begin{array}{l}5 \text { to } 15 \\
\text { minutes } \\
\square\end{array}$ & $\begin{array}{l}\text { Around the } \\
\text { house only } \\
\square\end{array}$ & $\begin{array}{c}\text { - pain severe } \\
\text { when walking } \\
\square\end{array}$ & 11 & During the $p$ & you do & usehold & 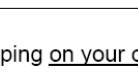 & \\
\hline & $\begin{array}{l}\text { During the past } 4 \mathrm{~V} \\
\text { After a meal }\end{array}$ & $\begin{array}{l}\text { weeks } \\
\text { (sat at a table) } \\
\text { up from a ch }\end{array}$ & w painful & it been for & to stand & & $\begin{array}{c}\text { Yes, } \\
\text { Easily } \\
\square\end{array}$ & $\begin{array}{c}\text { With little } \\
\text { difficulty } \\
\square\end{array}$ & $\begin{array}{c}\text { With moderate } \\
\text { difficulty } \\
\square\end{array}$ & $\begin{array}{c}\text { With extreme } \\
\text { difficulty } \\
\square\end{array}$ & $\begin{array}{c}\text { No, } \\
\text { Impossible } \\
\square\end{array}$ \\
\hline & $\begin{array}{l}\text { Not at all } \\
\text { painful }\end{array}$ & $\begin{array}{l}\text { Slightly } \\
\text { painful }\end{array}$ & $\begin{array}{l}\text { Moderately } \\
\text { painful }\end{array}$ & $\begin{array}{c}\text { Very } \\
\text { painful }\end{array}$ & & 12 & uring the pa & weeks..... & Ik down o & t of stairs? & \\
\hline & $\square$ & $\square$ & 口 & 口 & $\square$ & & $\begin{array}{l}\text { Yes, } \\
\text { Easily }\end{array}$ & & rate & me & \\
\hline & $\begin{array}{c}\text { During the past } 4 \mathrm{v} \\
\text { Have you }\end{array}$ & weeks been limping & en walking & cause of $y$ & knee? & & $\square$ & 口 & 口 & 口 & a \\
\hline & $\begin{array}{l}\text { Rarely/ } \\
\text { never } \\
\square\end{array}$ & $\begin{array}{c}\text { Sometimes, or } \\
\text { just at first } \\
\square\end{array}$ & $\begin{array}{c}\text { Often, not } \\
\text { just at first } \\
\square\end{array}$ & $\begin{array}{l}\text { Most of } \\
\text { the time } \\
\square\end{array}$ & $\begin{array}{c}\text { All of } \\
\text { the time } \\
\square\end{array}$ & & & & & & \\
\hline
\end{tabular}

Figure 1. The Oxford Knee Score.

The patients did not all have data available at all the different time points in this study. Several patients did not have a documented pre-operative score. To aid interpretation of the results, two sets of data analysis were performed. In the first, all available patient data was analysed to an end point of 10 years. In the second, patients who had no documented pre-operative OKS assessment were excluded from data analysis, leaving a total of 787 patients operated on with ten different models of prosthesis, and follow-up data available up to 5 years postoperatively. Data analysis was performed by a specialist statistician using SPSS software. The table illustrates the models of prosthesis that were used (Table 1).

We analysed the OKS reported by patients across the prostheses in use at the different time intervals (preoperative, 3 months, 12 months, 2 years, 5 years and 10 years).

\section{Results}

Table 2 illustrates the patient numbers at follow-up, and percentage lost to follow-up (Table 2) at each time interval, for all fifteen models of prosthesis. Overall follow-up rates averaged $48.0 \%$ at 3 -months and $58.1 \%$ at 12 months but only $7.6 \%$ at 5 years. This reflects the fact that some of the older models of prosthesis (most notably 3M, MG and STL) were followed up predominantly in the medium- to long-term (five to ten year post-operative periods) while others (such as NEX) have good data in the short term, but not in the long term.

The average OKS score pre-operatively was 15.8 (range 11.0 to 19.5), and at 3 months post-operatively was 39.4 (range 34.0 to 40.9) (Table 3). This was statistically significant for all models of prosthesis in the series with available pre-operative scores. Similar results were obtained at 12 months and beyond. There was no change in the OKS from 3 months onward to 2 years and beyond for all models of prosthesis.

Comparing data between the different models of prosthesis yielded no statistically significant differences in the average OKS between different models of prosthesis at any of the five post-operative time points studied (Figure 2). 
Table 1. List of knee prosthesis models used.

\begin{tabular}{ccc}
\hline Abbreviation & Prosthes & Number of patients \\
\hline PFC (Rasquinha et al. 2006) & Press fit condylar - Biomet & 404 \\
FUR & Furlong - JRI & 361 \\
TMT & Trabecular metal tibia - Zimmer & 328 \\
NEXGEN & NexGen - Zimmer & 264 \\
MG & Millar Galante & 61 \\
3M & 3M healthcare & 60 \\
LCCK & Legacy constrained condylar knee & 45 \\
UNI & Oxford & 20 \\
ENDO SL & LINK & 3 \\
LPS & NexGen by Zimmer & 2 \\
CUST & Custom-designed prosthesis & \\
\hline
\end{tabular}

Table 2. Total patient numbers and losses to follow-up by 10 years.

\begin{tabular}{cccccccccccccc}
\hline & Total & Pre-op & $\%$ loss & 3 mo & $\%$ loss & 12 mo & $\%$ loss & 2 y & $\%$ loss & 5 y & $\%$ loss & 10 y & $\%$ loss \\
\hline 3M & $\mathbf{6 7}$ & $\mathbf{0}$ & 100.0 & $\mathbf{0}$ & 100.0 & $\mathbf{0}$ & 100.0 & $\mathbf{1}$ & 98.5 & $\mathbf{3 9}$ & 41.8 & $\mathbf{5 2}$ & 22.4 \\
CUST & $\mathbf{1}$ & $\mathbf{0}$ & 100.0 & $\mathbf{0}$ & 100.0 & $\mathbf{0}$ & 100.0 & $\mathbf{0}$ & 100.0 & $\mathbf{0}$ & 100.0 & $\mathbf{1}$ & 0.0 \\
ENDO & $\mathbf{4}$ & $\mathbf{3}$ & 25.0 & $\mathbf{4}$ & 0.0 & $\mathbf{3}$ & 25.0 & $\mathbf{2}$ & 50.0 & $\mathbf{0}$ & 100.0 & $\mathbf{0}$ & 100.0 \\
FUR & $\mathbf{3 6 1}$ & $\mathbf{1 1 9}$ & 67.0 & $\mathbf{1 4 5}$ & 59.8 & $\mathbf{2 1 8}$ & 39.6 & $\mathbf{3 1 3}$ & 13.3 & $\mathbf{1 4 3}$ & 60.4 & $\mathbf{1 5}$ & 95.8 \\
GEN & $\mathbf{3}$ & $\mathbf{0}$ & 100.0 & $\mathbf{0}$ & 100.0 & $\mathbf{0}$ & 100.0 & $\mathbf{1}$ & 66.7 & $\mathbf{3}$ & 0.0 & $\mathbf{0}$ & 100.0 \\
LCCK & $\mathbf{6 0}$ & $\mathbf{4 1}$ & 31.7 & $\mathbf{4 6}$ & 23.3 & $\mathbf{4 3}$ & 28.3 & $\mathbf{1 9}$ & 68.3 & $\mathbf{0}$ & 100.0 & $\mathbf{0}$ & 100.0 \\
LPS & $\mathbf{1}$ & $\mathbf{1}$ & 0.0 & $\mathbf{1}$ & 0.0 & $\mathbf{0}$ & 100.0 & $\mathbf{0}$ & 100.0 & $\mathbf{0}$ & 100.0 & $\mathbf{0}$ & 100.0 \\
MG & $\mathbf{8 1}$ & $\mathbf{0}$ & 100.0 & $\mathbf{0}$ & 100.0 & $\mathbf{0}$ & 100.0 & $\mathbf{2 6}$ & 67.9 & $\mathbf{4 7}$ & 42.0 & $\mathbf{4 2}$ & 48.1 \\
NEX & $\mathbf{2 6 1}$ & $\mathbf{2 0 4}$ & 21.8 & $\mathbf{2 1 6}$ & 17.2 & $\mathbf{1 9 4}$ & 25.7 & $\mathbf{6 2}$ & 76.2 & $\mathbf{3}$ & 98.9 & $\mathbf{0}$ & 100.0 \\
NLPS & $\mathbf{2}$ & $\mathbf{2}$ & 0.0 & $\mathbf{2}$ & 0.0 & $\mathbf{1}$ & 50.0 & $\mathbf{0}$ & 100.0 & $\mathbf{0}$ & 100.0 & $\mathbf{0}$ & 100.0 \\
PFC & $\mathbf{4 0 4}$ & $\mathbf{1 0 8}$ & 73.3 & $\mathbf{2 2 3}$ & 44.8 & $\mathbf{2 5 6}$ & 36.6 & $\mathbf{1 8 0}$ & 55.4 & $\mathbf{2 8 1}$ & 30.4 & $\mathbf{2}$ & 99.5 \\
ROT.H & $\mathbf{1}$ & $\mathbf{1}$ & 0.0 & $\mathbf{1}$ & 0.0 & $\mathbf{0}$ & 100.0 & $\mathbf{0}$ & 100.0 & $\mathbf{0}$ & 100.0 & $\mathbf{0}$ & 100.0 \\
STL & $\mathbf{1 6}$ & $\mathbf{0}$ & 100.0 & $\mathbf{0}$ & 100.0 & $\mathbf{0}$ & 100.0 & $\mathbf{2}$ & 87.5 & $\mathbf{6}$ & 62.5 & $\mathbf{1 3}$ & 18.8 \\
TMT & $\mathbf{3 2 8}$ & $\mathbf{2 8 2}$ & 14.0 & $\mathbf{2 7 4}$ & 16.5 & $\mathbf{2 1 2}$ & 35.4 & $\mathbf{1 6}$ & 95.1 & $\mathbf{0}$ & 100.0 & $\mathbf{0}$ & 100.0 \\
UNI & $\mathbf{4 5}$ & $\mathbf{2 6}$ & 42.2 & $\mathbf{3 8}$ & 15.6 & $\mathbf{4 0}$ & 11.1 & $\mathbf{1 3}$ & 71.1 & $\mathbf{4}$ & 91.1 & $\mathbf{0}$ & 100.0 \\
Total & $\mathbf{1 6 3 5}$ & $\mathbf{7 8 5}$ & 52.0 & $\mathbf{9 5 0}$ & 41.9 & $\mathbf{9 6 7}$ & 40.9 & $\mathbf{6 3 4}$ & 61.2 & $\mathbf{5 2 6}$ & 67.8 & $\mathbf{1 2 5}$ & 92.4 \\
\hline
\end{tabular}

Table 3. Average OKS for all models of prosthesis across the 10 -year study period.

\begin{tabular}{|c|c|c|c|c|c|c|c|}
\hline & No of patients & Pre-op & $3 \mathrm{mo}$ & $12 \mathrm{mo}$ & $2 y$ & $5 y$ & $10 y$ \\
\hline $3 \mathrm{M}$ & 67 & & & & 44.0 & 37.2 & 37.2 \\
\hline CUST & 1 & & & & & & 44.0 \\
\hline ENDO & 4 & 11.7 & 34.0 & 31.7 & 26.5 & & \\
\hline FUR & 361 & 15.7 & 39.6 & 40.5 & 39.5 & 39.8 & 39.1 \\
\hline GEN & 3 & & & & 34.0 & 44.0 & \\
\hline LCCK & 60 & 13.8 & 36.6 & 37.1 & 35.2 & & \\
\hline LPS & 1 & 11.0 & 36.0 & & & & \\
\hline MG & 81 & & & & 41.5 & 42.4 & 38.4 \\
\hline NEX & 261 & 15.5 & 39.6 & 41.1 & 41.4 & 42.3 & \\
\hline NLPS & 2 & 12.0 & 36.5 & 47.0 & & & \\
\hline PFC & 404 & 15.0 & 40.4 & 41.4 & 41.5 & 42.0 & 43.0 \\
\hline ROT.H & 1 & 15.0 & 40.0 & & & & \\
\hline STL & 16 & & & & 32.5 & 32.7 & 37.8 \\
\hline TMT & 328 & 16.4 & 38.7 & 40.9 & 42.8 & & \\
\hline UNI & 45 & 19.5 & 40.9 & 43.2 & 42.5 & 40.8 & \\
\hline Total & 1635 & 15.8 & 39.4 & 40.9 & 40.6 & 40.8 & 38.1 \\
\hline
\end{tabular}




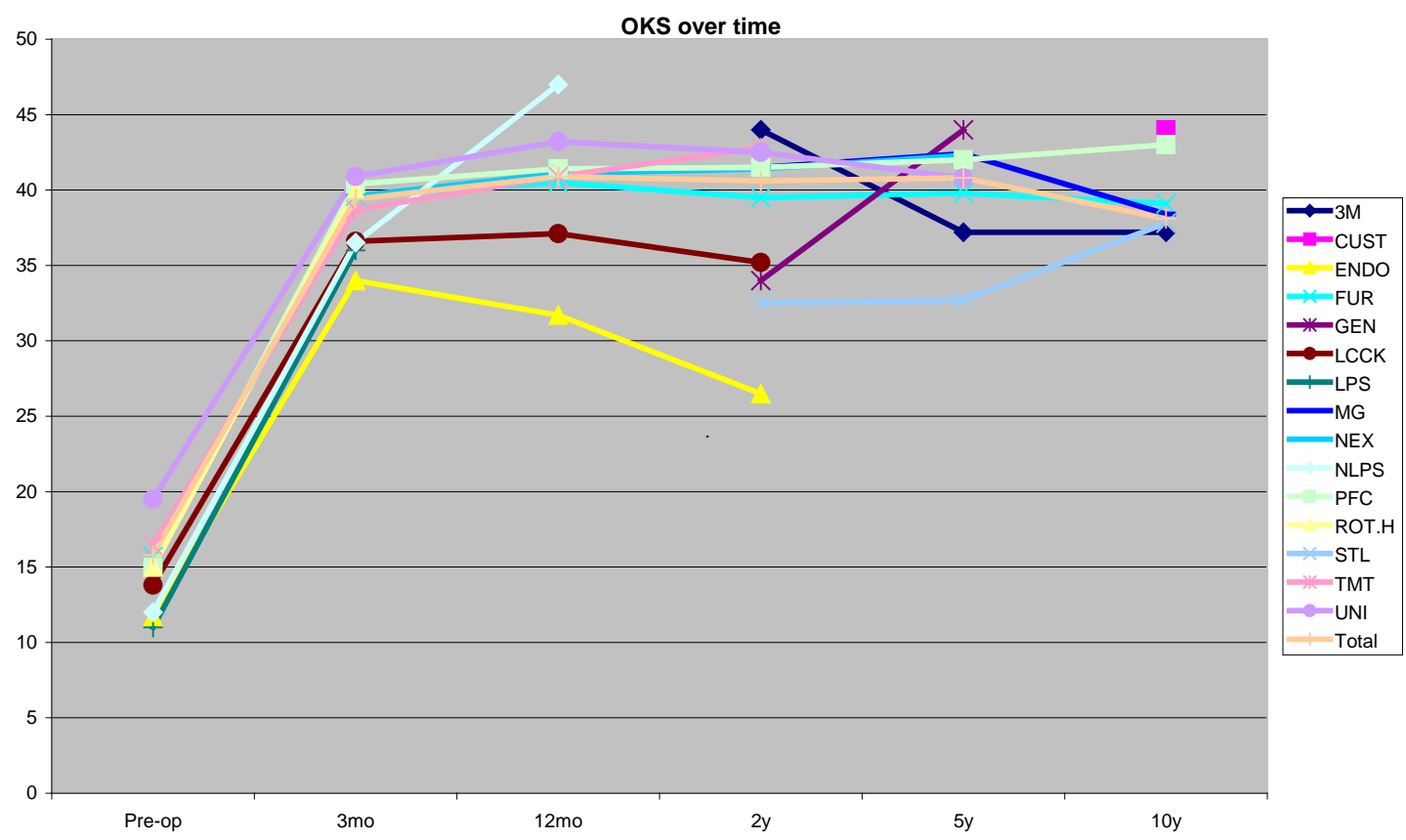

Figure 2. OKS over time for all models of knee prosthesis.

The NLPS had apparently worse scores and the ROT.H had apparently better scores in the medium term but with the very small sample size the results were not statistically significant. Although there were no pre-operative scores for a number of models of prosthesis (usually the older models), patient outcomes at 5 and 10 years postoperatively where available were comparable to the 5 and 10 year results of the newer models. Smaller numbers of patients were seen in the longer term follow-up groups due to patients being lost to follow-up.

Separating out the data for those patients who had both pre- and post-operative scores yielded some interesting results (Table 4). Although the total length of follow-up was only to 2 - 5 years in this group (Table 5), similar results to the initial larger patient group were obtained, with an average pre-operative OKS score of 15.8, increasing to 39.3 at 3 months post-operatively ( $\mathrm{p}$ value $=0.326$ ). The difference between the lowest-scoring prosthesis (LPS) and the others was not statistically significant, although the fact that there was only one patient in the LPS group biases this data. As before, there was no statistically significant change in the OKS from 3 months post-operatively to 10 years for all models of prosthesis with available data (Figure 3).

Thus, in this group of patients with available pre- and post-operative OKS scores we find a statistically significant increase in the OKS from the pre-operative to 3 month period, maintained at least as long as 2 years and up to 10 year post-operatively. We report no statistically significant difference in outcomes across all the prosthetic devices used $(\mathrm{p}=0.226)$.

\section{Discussion}

Our study did not find any significant difference in patient outcomes regardless of the model of prosthesis used. Patients reported significant benefit from total knee replacement by 3 months post-operatively, with the average OKS more than doubling. This benefit was maintained in the long-term, as shown by the minimal change in OKS score from 3 months to five years post-operatively. This strongly suggests that long-term functional outcomes, at least as determined by the OKS, are not influenced by the design of the prosthesis.

There is limited research comparing a broad range of prosthesis models over an extended period of time. Other studies with more limited scope in terms of patient numbers and length of follow-up appear to support our findings. As reported previously, the degree of familiarity of the surgeon with the prosthesis appeared to be a striking determinant of post-operative outcome [8]. Dermengian et al. [2] reviewed a number of studies comparing outcomes using a variety of prosthesis models over follow-up periods ranging from 12 months to 5 years. There were no convincing differences in outcomes in any of the studies comparing cruciate-sacrificing versus cruciate-retaining prostheses [13] [14], high-flexion versus standard prostheses [15] (Minoda et al. 2009) and mobile 
Table 4. Average OKS at follow-up for patients who had available pre-operative scores for comparison.

\begin{tabular}{cccccccc}
\hline & No of patients & Pre-op score & 3 months & 12 months & 2 years & 5 years & 10 years \\
\hline ENDO & 3 & 11.7 & 35.0 & 35.5 & 29.0 & - & - \\
FUR & 119 & 15.7 & 39.7 & 39.2 & 38.2 & 40.7 & - \\
LCCK & 41 & 13.8 & 36.7 & 37.5 & 33.6 & - & - \\
LPS & 1 & 11.0 & 26.0 & - & - & - & - \\
NEX & 204 & 15.5 & 40.0 & 41.0 & 40.9 & - & - \\
NLPS & 2 & 12.0 & 36.5 & 47.0 & - & - & - \\
PFC & 108 & 15.0 & 40.5 & 40.8 & 38.1 & - & - \\
ROT.H & 1 & 15.0 & 40.0 & - & - & - & - \\
TMT & 282 & 16.4 & 38.4 & 40.9 & 41.9 & - & - \\
UNI & 26 & 19.5 & 41.2 & 43.4 & 44.8 & - & - \\
Total & $\mathbf{7 8 7}$ & $\mathbf{1 5 . 8}$ & $\mathbf{3 9 . 3}$ & $\mathbf{4 0 . 6}$ & $\mathbf{3 9 . 1}$ & $\mathbf{4 0 . 7}$ & - \\
\hline
\end{tabular}

Table 5. For patients with pre-operative OKS scores-total numbers and losses to follow-up by 10 years.

\begin{tabular}{cccccccccccc}
\hline & Pre-op & 3 mo & \% lost & 12 mo & \% lost & 2 y & \% lost & 5 y & \% lost & 10 y & $\%$ lost \\
\hline ENDO & $\mathbf{3}$ & $\mathbf{3}$ & 0.0 & $\mathbf{2}$ & 33.3 & $\mathbf{1}$ & 66.7 & $\mathbf{0}$ & 100.0 & $\mathbf{0}$ & 100.0 \\
FUR & $\mathbf{1 1 9}$ & $\mathbf{6 6}$ & 44.5 & $\mathbf{9 0}$ & 24.4 & $\mathbf{5 3}$ & 55.5 & $\mathbf{3}$ & 97.5 & $\mathbf{0}$ & 100.0 \\
LCCK & $\mathbf{4 1}$ & $\mathbf{3 6}$ & 12.2 & $\mathbf{3 1}$ & 24.4 & $\mathbf{1 0}$ & 75.6 & $\mathbf{0}$ & 100.0 & $\mathbf{0}$ & 100.0 \\
LPS & $\mathbf{1}$ & $\mathbf{1}$ & 0.0 & $\mathbf{0}$ & 100.0 & $\mathbf{0}$ & 100.0 & $\mathbf{0}$ & 100.0 & $\mathbf{0}$ & 100.0 \\
NEX & $\mathbf{2 0 4}$ & $\mathbf{1 8 3}$ & 10.3 & $\mathbf{1 4 7}$ & 27.9 & $\mathbf{4 1}$ & 79.9 & $\mathbf{0}$ & 100.0 & $\mathbf{0}$ & 100.0 \\
NLPS & $\mathbf{2}$ & $\mathbf{2}$ & 0.0 & $\mathbf{1}$ & 50.0 & $\mathbf{0}$ & 100.0 & $\mathbf{0}$ & 100.0 & $\mathbf{0}$ & 100.0 \\
PFC & $\mathbf{1 0 8}$ & $\mathbf{9 4}$ & 13.0 & $\mathbf{7 2}$ & 33.3 & $\mathbf{2 0}$ & 81.5 & $\mathbf{0}$ & 100.0 & $\mathbf{0}$ & 100.0 \\
ROT.H & $\mathbf{1}$ & $\mathbf{1}$ & 0.0 & $\mathbf{0}$ & 100.0 & $\mathbf{0}$ & 100.0 & $\mathbf{0}$ & 100.0 & $\mathbf{0}$ & 100.0 \\
TMT & $\mathbf{2 8 2}$ & $\mathbf{2 4 3}$ & 13.8 & $\mathbf{1 7 7}$ & 37.2 & $\mathbf{1 2}$ & 95.7 & $\mathbf{0}$ & 100.0 & $\mathbf{0}$ & 100.0 \\
UNI & $\mathbf{2 6}$ & $\mathbf{2 5}$ & 3.8 & $\mathbf{2 2}$ & 15.4 & $\mathbf{5}$ & 80.8 & $\mathbf{0}$ & 100.0 & $\mathbf{0}$ & 100.0 \\
Total & $\mathbf{7 8 7}$ & $\mathbf{6 5 4}$ & 16.9 & $\mathbf{5 4 2}$ & 31.1 & $\mathbf{1 4 2}$ & 82.0 & $\mathbf{3}$ & 99.6 & $\mathbf{0}$ & 100.0 \\
\hline
\end{tabular}

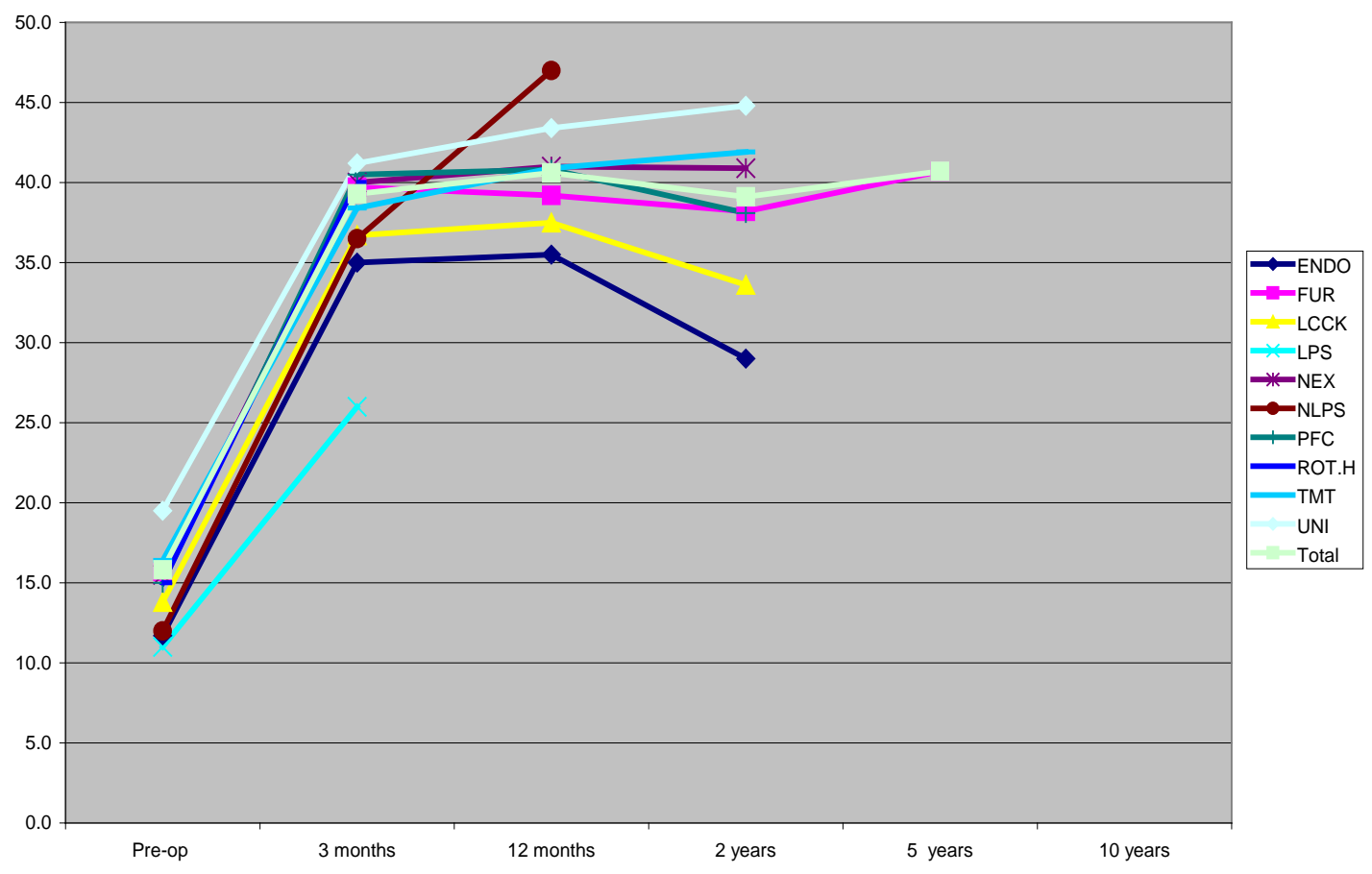

Figure 3. OKS over time for patients with available pre-operative scores. 
versus fixed prostheses [15] (Gioe et al. 2009). All these studies had smaller patient numbers with duration of follow-up between 12 months and 5 years.

The UK Knee Arthroplasty Trial [16] (Johnston et al. 2009) was a multicentre randomised controlled trial involving 116 surgeons, with 2352 patients allocated to treatment with or without a metal backing of the tibialcomponent (409 patients), with or without patellar resurfacing (1715 patients), and/or with or without a mobile bearing prosthesis (539 patients). The primary outcome measures were OKS, other functional and quality of life scores (Short Form-12, EuroQol-5D) and the need for additional surgery. The results up to two years post-operatively showed that functional status and quality-of-life scores were low at baseline (pre-operatively) but improved markedly across all trial groups following knee replacement (mean OKS 17.98 at baseline and 34.82 points at two years post-operatively); this outcome is similar to our results. They reported no evidence of any differences in clinical or functional outcomes between these patient groups at two years.

There has been a recent drive towards investigating the possibility of improving patient outcomes using custom-designed prostheses. One study examining the outcomes of custom-designed prostheses took patients' preoperative computed tomography images and used these to model individualised prostheses [17]. These patientspecific prostheses would be associated with increased operative costs, which could be justified if there was evidence of significant overall long-term benefit to the patient. This requires further development and evaluation with well-designed clinical trials.

Our study had a number of limitations, one of which was the number of losses to follow up. This had a number of causative factors, including patient non-attendance at clinic and patient death. Some models of prosthesis were only used in a small number of patients, limiting the statistical power of the study. Also, for some of the older models, no pre-operative scores were available, so no direct comparison between patient outcomes preand post-surgery could be made. However, for a large patient series over an extended follow-up period (up to 10 years), we are able to show no evidence of any difference in functional outcome in patients for any of the fifteen models of prosthesis used.

\section{Conclusions}

The search continues to find the optimum prosthesis for knee replacement. Due to the many available designs on the market, it is imperative that the surgeon makes an informed choice about the ideal prosthesis for each patient. With current demographic trends and a rapidly increasing demand for this procedure, an understanding of the ways in which prosthetic design can influence post-operative outcomes in terms of the risk of complications, as well as functional and quality of life outcomes for patients, is crucially important.

Based on currently available data from our study and the literature available, we can conclude that at this point in time, there is no convincing evidence that any of the models and designs currently in use offers any advantage over any other. Further research using prospective randomised studies with larger patient numbers and lower rates of attrition would be beneficial in further exploring this evolving field.

\section{References}

[1] The National Joint Registry. http://www.njrcentre.org.uk/njrcentre/default.aspx

[2] Deirmengian, C.A. and Lonner, J.H. (2010) What's New in Adult Reconstructive Knee Surgery. Journal of Bone and Joint Surgery. American Volume, 92, 2753-2764. http://dx.doi.org/10.2106/JBJS.J.01202

[3] Rand, J.A. and Ilstrup, D.M. (1991) Survivorship Analysis of Total Knee Arthroplasty. Cumulative Rates of Survival of 9200 Total Knee Arthroplasties. Journal of Bone and Joint Surgery, American Volume, 73, 397-409.

[4] Tsao, A., Mintz, L., McRae, C.R., Stulberg, S.D. and Wright, T. (1993) Failure of the Porous-Coated Anatomic Prosthesis in Total Knee Arthroplasty Due to Severe Polyethylene Wear. Journal of Bone and Joint Surgery. American Volume, 75, 19-26.

[5] Innocenti, M., Civinini, R., Carulli, C., Matassi, F. and Villano, M. (2010) The 5-Year Results of an Oxidized Zirconium Femoral Component for TKA. Clinical Orthopaedics and Related Research, 468, 1258-1263. http://dx.doi.org/10.1007/s11999-009-1109-y

[6] Roualdes, O., Duclos, M.E., Gutknecht, D., Frappart, L., Chevalier, J. and Hartmann, D.J. (2010) In Vitro and in Vivo Evaluation of an Alumina-Zirconia Composite for Arthroplasty Applications. Biomaterials, 31, 2043-2054. http://dx.doi.org/10.1016/j.biomaterials.2009.11.107

[7] Kim, Y.H., Choi, Y. and Kim, J.S. (2011) Comparison of a Standard and a Gender-Specific Posterior Cruciate-Substi- 
tuting High-Flexion Knee Prosthesis. A Prospective, Randomized, Short-Term Outcome Study. Journal of Bone and Joint Surgery. American Volume, 93, e12.

[8] Robertsson, O., Lewold, S., Knutson, K. and Lidgren, L. (2000) The Swedish Knee Arthroplasty Project. Acta Orthopaedica Scandinavica, 71, 7-18. http://dx.doi.org/10.1080/00016470052943829

[9] Dawson, J., Fitzpatrick, R., Murray, D. and Carr, A. (1998) Questionnaire on the Perceptions of Patients about Total Knee Replacement. Journal of Bone and Joint Surgery. British Volume, 80, 63-69. http://dx.doi.org/10.1302/0301-620X.80B1.7859

[10] Dunbar, M.J., Robertsson, O., Ryd, L. and Lidgren, L. (2000) Translation and Validation of the Oxford-12 Item Knee Score for Use in Sweden. Acta Orthopaedica Scandinavica, 71, 268-274. http://dx.doi.org/10.1080/000164700317411861

[11] Naal, F.D., Impellizzeri, F.M., Sieverding, M., Loibl, M., von Knoch, F., Mannion, A.F., Leunig, M. and Munzinger, U. (2009) The 12-Item Oxford Knee Score: Cross-Cultural Adaptation into German and Assessment of Its Psychometric Properties in Patients with Osteoarthritis of the Knee. Osteoarthritis Cartilage, 17, 49-52. http://dx.doi.org/10.1016/j.joca.2008.05.017

[12] Murray, D.W., Fitzpatrick, R., Rogers, K., Pandit, H., Beard, D.J., Carr, A.J. and Dawson, J. (2007) The Use of the Oxford Hip and Knee Scores. Journal of Bone and Joint Surgery, British Volume, 89, 1010-1014. http://dx.doi.org/10.1302/0301-620X.89B8.19424

[13] Kim, Y.H., Choi, Y., Kwon, O.R. and Kim, J.S. (2009) Functional Outcome and Range of Motion of High-Flexion Posterior Cruciate-Retaining and High-Flexion Posterior Cruciate-Substituting Total Knee Prostheses. A Prospective, Randomized Study. Journal of Bone and Joint Surgery, American Volume, 91, 753-760. http://dx.doi.org/10.2106/JBJS.H.00805

[14] Minoda, Y., Aihara, M., Sakawa, A., Fukuoka, S., Hayakawa, K. and Ohzono, K. (2009) Range of Motion of Standard and High-Flexion Cruciate Retaining Total Knee Prostheses. Journal of Arthroplasty, 24, 674-680. http://dx.doi.org/10.1016/j.arth.2008.02.015

[15] Gioe, T.J., Glynn, J., Sembrano, J., Suthers, K., Santos, E.R. and Singh, J. (2009) Mobile and Fixed-Bearing (AllPolyethylene Tibial Component) Total Knee Arthroplasty Designs. A Prospective Randomized Trial. Journal of Bone and Joint Surgery, American Volume, 91, 2104-2112. http://dx.doi.org/10.2106/JBJS.H.01442

[16] KAT Trial Group, Johnston, L., MacLennan, G., McCormack, K., Ramsay, C. and Walker, A. (2009) The Knee Arthroplasty Trial (KAT) Design Features, Baseline Characteristics, and Two-Year Functional Outcomes after Alternative Approaches to Knee Replacement. Journal of Bone and Joint Surgery. American Volume, 91, 134-141. http://dx.doi.org/10.2106/JBJS.G.01074

[17] Harrysson, O.L., Hosni, Y.A. and Nayfeh, J.F. (2007) Custom-Designed Orthopedic Implants Evaluated Using Finite Element Analysis of Patient-Specific Computed Tomography Data: Femoral-Component Case Study. BMC Musculoskeletal Disorders, 8, 91. http://dx.doi.org/10.1186/1471-2474-8-91 
Scientific Research Publishing (SCIRP) is one of the largest Open Access journal publishers. It is currently publishing more than 200 open access, online, peer-reviewed journals covering a wide range of academic disciplines. SCIRP serves the worldwide academic communities and contributes to the progress and application of science with its publication.

Other selected journals from SCIRP are listed as below. Submit your manuscript to us via either submit@scirp.org or Online Submission Portal.
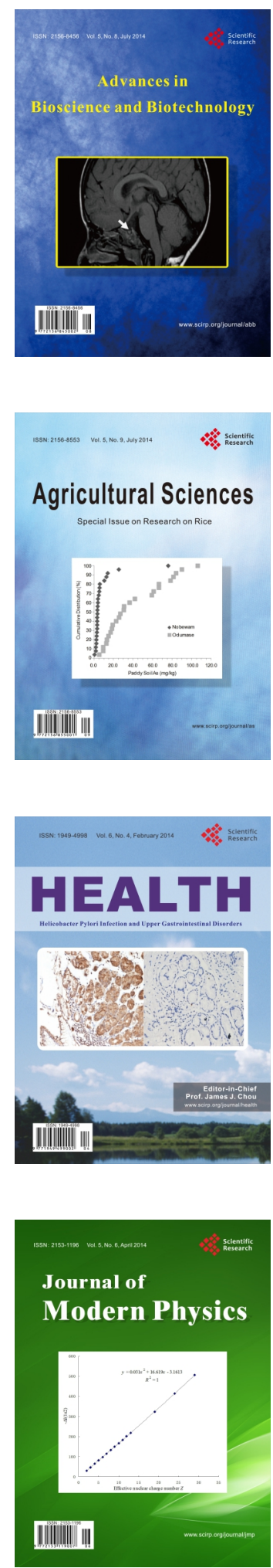
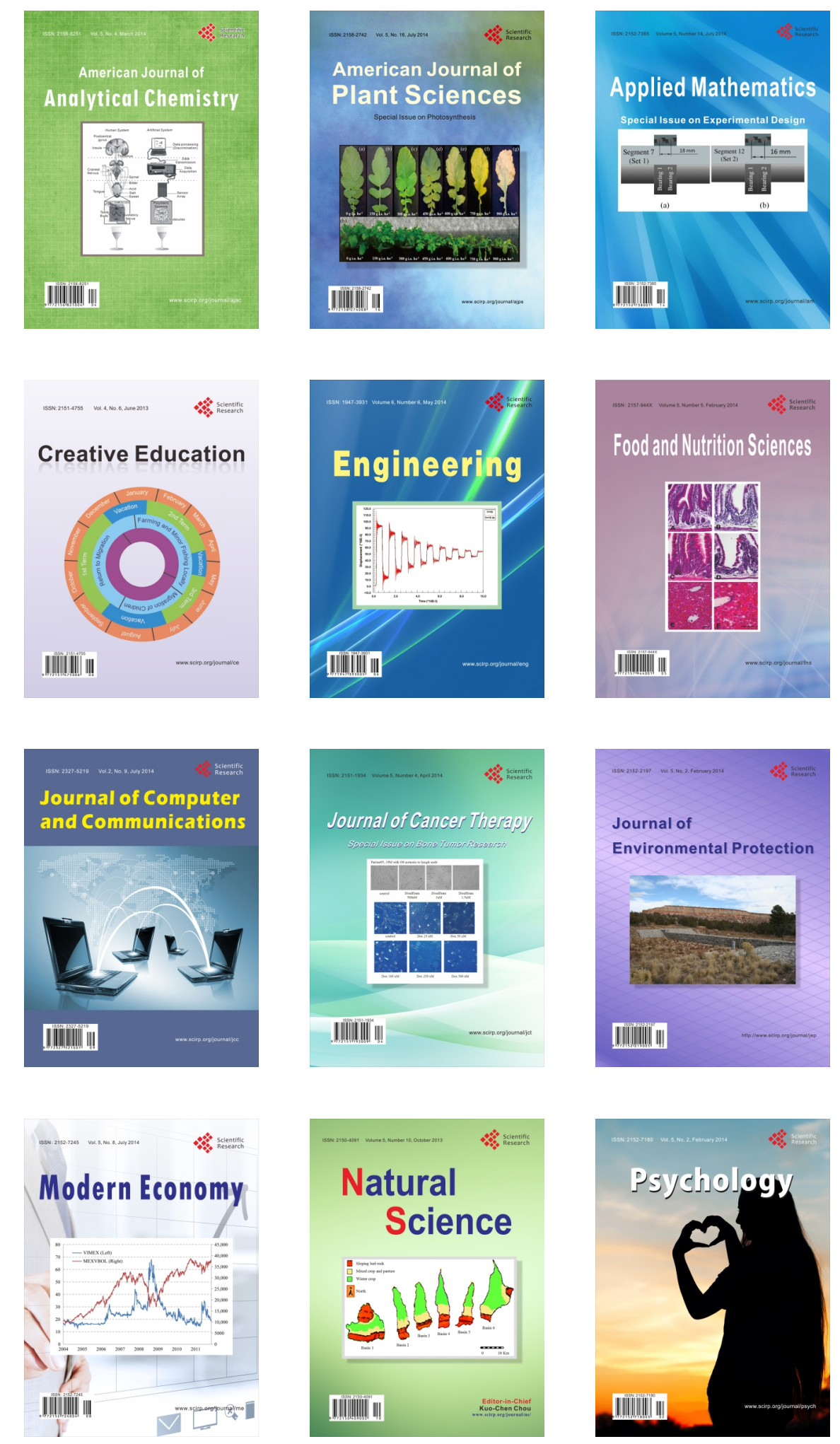